\title{
Science as a Democratic Life-Function and the Challenge of Scientism
}

Matthias Jung

\section{OpenEdition}

1 Journals

\section{Electronic version}

URL: http://journals.openedition.org/ejpap/2112

DOI: 10.4000/ejpap.2112

ISSN: 2036-4091

\section{Publisher}

Associazione Pragma

\section{Electronic reference}

Matthias Jung, "Science as a Democratic Life-Function and the Challenge of Scientism », European Journal of Pragmatism and American Philosophy [Online], XII-2 | 2020, Online since 14 December 2020, connection on 15 December 2020. URL : http://journals.openedition.org/ejpap/2112 ; DOI : https:// doi.org/10.4000/ejpap.2112

This text was automatically generated on 15 December 2020.

\section{$(\mathbb{\theta} \Theta \Theta$}

Author retains copyright and grants the European Journal of Pragmatism and American Philosophy right of first publication with the work simultaneously licensed under a Creative Commons AttributionNonCommercial-NoDerivatives 4.0 International License. 


\title{
Science as a Democratic Life- Function and the Challenge of Scientism
}

\author{
Matthias Jung
}

\section{Introduction}

1 I'd like to start with a truism: Science is a crucial factor in the functioning of modern national states, of the tightly connected web of global economy and of the emerging world society. The current global crisis caused by the covid-19 pandemic offers ample proof for this fact: without the transportation-technology driven by science, the virus would never have had the chance to spread as quickly as it actually did, but without science we would also be completely lost and helpless pertaining to how we should cope with the situation. Nevertheless, we are used to consider the science-system as something largely driven by its own, internal logic of inquiry and connected with the rest of society mainly via two constitutive relations, one input- and one output-related: political institutions regulate the cash-flow providing science with the means for its investigations (e.g. the development of a vaccination), whereas the technological output of science continues to transform economy and everyday life (e.g. the pandemic will likely soon be over once a vaccination will be accessible for large parts of the global population).

2 As a rough and vastly oversimplified sketch, the input-output model surely contains some truths, but it leaves crucial questions unanswered. Is science dependent upon the specific form of political government and social division of labor in which it is embedded? Does it presuppose political freedom and the division of powers? Or is its internal logic compatible with different political systems? The fact that e.g. research in A.I. or genetics flourishes in nondemocratic societies such as China seems to provide evidence that the latter is the case. But it has also been argued that it is, at least in the long run, true that the principles of inquiry operative within science are internally 
connected with the free exchange of opinions and the possibility of uninhibitedly articulating dissent which are associated with democratic societies. John Dewey is the most vigorous proponent of this idea. Strongly opposed to dualisms and rigid separations as he was, Dewey emphasized the structural similarity between ordinary experience with its egalitarian and collaborative form on the one hand and scientific rationality on the other. Furthermore, he identified democracy with organized intelligence and saw a strong internal connection between the scientific spirit and the values keeping democracy alive: "[T]he spiritual basis of democracy," Dewey wrote in 1903, is "the efficacy and responsibility of freed intelligence" (Dewey 1903/2008: 236) and "the methods pursued by the scientific inquirer [,] give us an exact and concrete exhibition of the path which intelligence takes when working most efficiently [...]" (ibid.: 239). More precisely, he believed that "the specific cognitive virtues of science [...] - free inquiry, toleration of diverse opinion, and free communication - were necessary if not sufficient attributes of a democratic society and polity" (Westbrook 1991: 170). Hilary and Ruth Anna Putnam have recently argued much in the same line, following Dewey, and have underlined that both science and democracy presuppose the values of open communication and a fallibilistic attitude (Putnam \& Putnam 2017: 433-5).

\section{Science, (Communication) Technology, and Democracy}

But even if we bracket the question about the existence of internal relations between democracy and science it remains a truism that modern societies are shaped by science and science-driven technology in every imaginable manner. It is a safe bet that the likely progress of artificial intelligence during the next decades will deepen this influence in a hitherto unprecedented degree. But while it is evident that scientific progress has in many cases accompanied and also facilitated the development of democratic societies, we have neither evidence from history nor any metaphysical guarantees for a pre-established harmony between the two. Steven Pinker, in his exceedingly optimistic book Enlightenment Now - The Case for Reason, Science, Humanism, and Progress (Pinker 2018, esp. 199-213) depicts the ideals mentioned in his book's subtitle and the rise of democracy as inextricably bound together, but even he would probably be more cautious in the light of last year's developments. And pertaining to the ideal of democratic participation and social equality, the seemingly inevitable intrusion of AI and other technological developments into the infrastructure of human interaction raises deep and disturbing questions. To name only one: when the social life-world in which democratic values are developed and shared becomes more and more impregnated with activities enabled by information technology in the first place, the algorithms running on the necessary devices and networks will increasingly impact democratic procedures and facilitate manipulation. In Dewey's own account of democracy, face to face-communication takes precedence. ${ }^{1}$ But almost a century ago it was completely impossible to foresee the degree in which social exchange would be changed by the internet and the quasi-monopolist companies shaping its form. The driving forces behind these developments are completely out of democratic control, as for example the election campaign of 2016 in the U.S. has shown. It is for these and many other reasons that VR-pioneer Jaron Lanier, already in 2006 in an article titled 
"Beware the online collective" and elsewhere, expressed deep concerns about what he calls the "global flood of anonymous mob-like commentary" (Lanier 2006) and other distortions of democratic communication.

Couched in more general terms, these threats to democracy belong to the problem of the interplay between social values, scientific inquiry and technological developments. For pragmatist philosophers, science and technology are important, but neither independent nor privileged components of the social life-process, the interactional cycle between social organisms and their environments. Increasing democratic participation and enabling personal and communal growth are, according to Dewey, human values to which science and technology should be subordinated. As he writes in his last book, lost and then recently found again, the problem of (scientific) knowledge, "in its widest and deepest sense is a moral problem, understanding by 'moral' the question of human values as far as they are capable of being forwarded and expanded, retarded and frustrated, by deliberate human conduct" (Dewey 2012: 112). Modern pragmatist philosophers of science, most notably Philip Kitcher, have taken up these themes and underlined the value-entanglements of science as well as the need for democratic control. According to Kitcher, a well-ordered science would treat knowledge as a public good (Kitcher 2011: 241), and not leave the course of inquiry and technological developments to be determined by the interests of profit-makers and affluent societies, as it continues to happen today for example in disease and vaccination research. Well-ordered science would make room for the quest for knowledge as an end in itself, a consummative experience, but it would give primacy to the pursuit of humane values embedded within society's life-process and shaped by non-scientific social experiences. Achieving such a normative understanding of science is of the utmost importance for any emphatic vision of democracy, since it is only scientific inquiry that provides us with the means to effectively manipulate nature in the service of moral values in Dewey's sense.

5 Yet even Kitcher's sensitive account has a hard time coping with the tension between what one could call the internal democracy of educated experts within scientific inquiry and the inclusive democracy of all citizens within a society, educated or not. Hostility against scientific research and its results, so wide-spread in contemporary democracies, will not disappear even if the citizen juries Kitcher suggests ("small but representative groups of citizens being tutored in particular aspects of scientific research and then deliberating with one another about what courses of action would be most beneficial for all," Kitcher 2011: 233) would be a well-established feature of all democracies. The success of science depends upon adherence to the principle of selecting and educating cognitive elites whereas the success of democracy depends upon broad participation irrespective of cognitive capacities and education. This inevitable tension is enlarged by a public dimension of science to which - as far as I can see - Kitcher pays no special attention: its influence on comprehensive worldviews.

\section{Science, Scientism and the Problem of Worldviews}

6 Comprehensive worldviews, in the form of both religions and secular attitudes or doctrines, are important factors in the functioning of modern societies. Naturally, the impact of those worldviews has changed massively in late modernity with large-scale processes like religious individualization, pluralization, and secularization. But the fact 
that the dominance of a single religion and its social-integrative function characteristic for traditional societies has in modern democracies been replaced by a multitude of diverging religious and secular options has not diminished the impact of those comprehensive attitudes. As William James has argued forcefully, human beings tend to strife for a certain degree of unity among their manifold relationships to the world, a unity often experienced in an emotional manner and only ex post articulated in comprehensive worldviews. ${ }^{2}$ The "philosophy" (the word used in a very large and nontechnical sense) of a person, James holds, "is only partly got from books: it is our individual way of just seeing and feeling the total push and pressure of the cosmos" (James 1907/1981: 7). Nowadays, due to the omnipresence of science and science-driven technology in modern life, many people, including many scientists, tend to invest science with the authority to speak the last word in matters of comprehensive worldviews. Yet, as I have tried to show elsewhere (Jung 2019), worldviews deal with reality from the viewpoint of its - comprehensive and final - meaning, which inevitably introduces the engaged perspective of the first person. If any given worldview is to satisfy minimal conditions of rationality, factual and causal knowledge have to be respected - a condition that quickly rules out any religious fundamentalism. But it will always contribute only necessary, never satisfying conditions. Nevertheless, contemporary public discourse is characterized by many deep-seated confusions pertaining to the relation between science and worldviews, and the probably most tenacious one is called by the name of scientism.

7 Here we have another side of the mutual entanglement of science and social values, one which has not yet received much attention, but still plays an important, ever-growing, and often detrimental role in modern societies, namely the problematic inflation of science to a generalized world-view. Unfortunately, the term scientism suffers from many excessively vague uses and sometimes indeed shrinks to what Steven Pinker has called a mere "boo-word" (Pinker 2013). This can happen for example when proponents of the humanities use it to discredit the claims of natural scientists to expand the scope of their research into areas hitherto reserved for the hermeneutic disciplines. Nevertheless, if used with the necessary precision and care, the charge of scientism seems to me to address an actual, important, and ever-growing problem pertaining to the relation of science to the social life-process. Scientism, I propose, can be diagnosed validly, whenever scientific knowledge is inflated beyond its legitimate borders to include value-questions and especially a generalized understanding of reality as such. Two misunderstandings have to be avoided here: firstly, it is of course not in the least scientistic to strife for compatibility with scientific knowledge as far as one's worldview is concerned. To the contrary, doing so is a presupposition of any rational attitude towards reality in general. Rejecting scientism is very different from rejecting science, and it is a major shortcoming of Pinker's contribution to The New Republic mentioned above that he fails to make this distinction. Secondly, there also is nothing wrong with trying to base a comprehensive worldview on science. This worldview, though, will then inevitably have to extrapolate scientific knowledge and integrate valueassumptions as well as emotional attitudes, and will thus, admittedly or not, have to open the door for non-scientific modes of experience. John Dewey's naturalistic humanism, based not only on science but also on non-epistemic modes of experience like art and morals, is a case in point. 
What is so bad about scientism, especially when it comes to the flourishing of the democratic life? Scientism disables us to see the crucial importance of what Dewey called "the qualitative" for democracy, that is the basic fact that "the world in which we immediately live, ${ }^{3}$ that in which we strive, succeed and are defeated is preeminently a qualitative world. What we act for, suffer, and enjoy are things in their qualitative determinations." (Dewey 1930/2008: 243). Abstracting from the first-personal, qualitative involvement with reality is constitutive for science but detrimental for democratic life since it makes invisible what people actually care about. ${ }^{4}$ Scientism reduces the manifold of human forms of experience to a single form, namely science, taken to be exclusively truth-revealing and getting us in touch with reality with a big R. Theory reduction, when taking place within science, is an important part of scientific methodology. But it should not be confused with the reduction of non-scientific to scientific experience. When science alone is taken to be the arbiter of the existence of everything, then interpersonal, aesthetic, religious, moral, practical etc. experiences are inevitably reduced to an epiphenomenal status and a fatal, anti-democratic dichotomy between the scientifically enlightened few and the large majority of the uneducated dwellers in Plato's cave is created.

It is, for example, a direct consequence of neuro-constructivist positions like Thomas Metzinger's, that ordinary people are confined to the mental illusion of reality their brains produce for them whereas only the neuro-philosopher is able to break through to what actually counts ontologically: the brain and its workings. "As a matter of fact, we are ourselves systems which constantly 'confuse' themselves with the subsymbolic self-model they have created. In doing so, we create a stable and coherent 'self-illusion' which we are unable to transcendent on the level of our conscious experience." (Metzinger 1998: 361; my translation). But, luckily for the scientists, Metzinger also claims: "On the level of theory-building, we are able to break through our naiverealistic self-understanding." (Ibid.: 365; my translation). If this two-tiered structure were true, it would be very bad news for anyone still concerned with the democratic ideal of communication among equals as the basis for social life. The vast majority of people would be lost in an evolutionary useful illusion, whereas only cognitive scientists would be able to actually get in touch with reality - albeit only as scientists, not in their everyday life as partners, mothers or fathers, citizens, voters etc. Illusionary subjects, endowed by morality and law with illusionary dignity, would be the quicksand on which democratic discourse would be built upon.

Neuro-constructivism is among the most radical forms of scientism, but its softer versions are no less disturbing for any meaningful conception of democracy, given the fact that any open society will contain citizens with many different takes on religious and worldview-questions. Devaluating their deepest convictions as inherently irrational is one of the most effective discussion-blockers imaginable. Take, for example, Steven Pinker once again. He contends that "the worldview that guides the moral and spiritual values of an educated person today is the worldview given to us by science" (Pinker 2013). This implies that e.g. Christians, Jews, or Muslims, since their moral and spiritual values are not drawn from science, do not belong to the realm of educated people and are therefore severely handicapped regarding their ability to participate in democratic discussions. But even for adherents of worldview naturalism, the idea of science as giving us moral and even spiritual guidance makes no sense. Commitment to an ontology for which reality is coextensive with the findings of 
science does not suffice to produce a full-fledged worldview. One still has to integrate e.g. moral and aesthetic values, something which presupposes leaving the neutral scientific attitude and adopting the stance of human beings having to live a life and caring about it. To claim that the scientific stance in itself already contains moral and other values to live by in one's everyday life runs straight against the methodological constraints of science. Furthermore, and apart from the question of values, Pinker seems to be convinced that science delivers more than fallible, but often very reliable truth, namely an understanding of the world gradually approaching totality. Instead of demanding compatibility with science, something which is crucial for all liberal and enlightened versions of religions and worldviews, he identifies the scientific stance with a comprehensive picture of reality. This excludes not only all sorts of religious attitudes, even what Kitcher calls refined religions, ${ }^{5}$ strictly speaking it even eliminates secular humanism. This world-view attitude, wide-spread among scientists as it may be, can evidently not be based upon science alone. The scientific stance, albeit imbedded into values developed in ordinary experience and to a large degree motivated by the desire to understand and control nature in accordance with these values, is constituted by the bracketing of our ordinary, value- and interest-driven point of view. Therefore, as argued above, the aesthetic, evaluative and normative dimensions of e.g. secular humanism can never be derived from science. There is no such thing as a scientific worldview, only science-compatible and incompatible worldviews.

11 Like it or not, world-views and religions, that is comprehensive attitudes towards reality in general, play an important role in shaping the attitudes of the members of democratic communities. I take this to be an empirical truth which is hard to deny, and it should be kept clearly distinct from the very different claim, made prominent by Richard Rorty (1989), that the contingency of all cultural artefacts effectively destroys the possibility of comprehensive attitudes which include truth-claims. Even someone who argues that the world would be a better place if people refrained from generalized religious or secular attitudes towards life and the world must admit that in the world as it actually is such attitudes continue to exert their influence. Among the pragmatist philosophers it was William James who pointed out time and again how deeply human conduct is shaped by "a man's total reaction upon life" (James 1902/1990: 39). According to James, we cannot avoid at least to live an answer to the question "What is the character of this universe in which we dwell?" (ibid.). James also insisted that quite often, anti-religious attitudes are akin to religious ones in the importance they gain for the identity of the respective persons: "[...] the more fervent opponents of Christian doctrine have often enough shown a temper which, psychologically considered, is indistinguishable from religious zeal." (Ibid.). This statement from 1902 can easily be applied to contemporary writers like Richard Dawkins, Sam Harris, Christopher Hitchens and Daniel Dennett. Relaxed ironists à la Rorty are different of course; but even they, albeit rejecting any cognitive generalization, are characterized by a certain unifying attitude towards life in general.

12 The next step must now be to connect James's anthropological insight into the importance of attitudes towards life with Dewey's emphatic - and anti-individualistic understanding of democracy as a form of life. In his Democracy and Education, Dewey underlines that "democracy is more than a form of government; it is primarily a mode of associated living, of conjoint communicated experience" (Dewey 1916/1985: 93). And he relates this ideal directly to the diversity of interests, attitudes and experiences human beings exhibit: "more numerous and more varied points of contact denote a 
greater diversity of stimuli to which an individual has to respond." (Ibid.). The goal is a "widening of the area of shared concerns, and the liberation of a greater diversity of personal capacities which characterize a democracy" (ibid.). Dewey himself does not relate his ideals of "shared concerns" and "greater diversity" to the varieties of worldviews, and his own handling of worldview pluralism is hampered by his quasireligious faith in democracy. ${ }^{6}$ But given the empirical reality of an irreducible multitude of comprehensive attitudes and doctrines, it seems important not to exclude them from the emphatic concept of democratic conversation which Dewey sees as the hallmark of democracy as a form of life. If scientism would acquire a hegemonic status in public discourse, the deepest convictions human beings hold and the values they cherish most would (with the exception of scientistic humanists) be excluded from the public realm. ${ }^{7}$ To be sure, the problem of worldview-hegemony holds for any comprehensive doctrine, especially for religious ones. Worldview- and religious pluralism is the most demanding and difficult case of "shared common interest," and always endangered by withdrawals of the respective communities into their internal communal life, or even worse, by aggressive or even violent attacks on dissenters.

The pluralism Dewey has in mind exhibits two distinct features: it acknowledges the historical and biographical contingencies of human experience as intrinsically valuable, and it also makes room for the variety of different aspects of experience. Human beings differ in their perception and articulation of comparable experiential qualities, and they also differ as to the irreducible multitude of modes of experience. Both features are denied when science is extrapolated into a comprehensive worldview without the acknowledgment that by doing so one enters the realm of first-personal, non-scientific experience. It is the lack of this acknowledgement that constitutes scientism, not the fact that someone tries to extrapolate a worldview from science.

Since at the heart of scientism lies the rejection of non-scientific modes of experience, it cannot do without a deep social division between scientists and, bluntly put, the rest. Hence, the political correlate of scientism is not democracy, but an expertocracy or technocracy, ${ }^{8}$ in which the relevance of diverse modes of experience is rejected, and along with it the normative ideal of equality. The neuroscientist David Eagleman, to provide just one example, sees science as effectively deconstructing the ideal of equality, which he takes to be a pre-(neuro-)scientific myth (Eagleman 2012, chap. 6). His scientistic inference (the term "naturalistic fallacy" would be more appropriate) goes from the factual unequality of human brains - which are without further ado taken to be standing for the human person in toto - to the normative obsoleteness of equality. Thus, for him only experts, or more precisely neuroscientists, are competent to make the right decisions. "My dream," Eagleman tells his readers, "is to build an evidence based, neurally compatible social policy instead of one based on shifting and provably bad intuitions" (Eagleman 2012: 192). From this angle, the Universal Declaration of Human Rights probably counts as one of those shifting intuitions, since it is definitely not based on reflection upon the workings of the human brain. Eagleman leaves no doubt that the necessary evidence for social policies can only be provided by neuroscientists, whereas the "provably bad intuitions" come from scientific laypeople. Democratic deliberations encompassing all citizens are entirely left out of his scientistic picture.

Eagleman's dream is Dewey's worst nightmare. The pragmatist philosopher has developed convincing arguments against any contraposition of experts and the masses. 
Mark B. Brown sums them up succinctly in three points: "First, if the masses are incompetent, as technocrats assume, they will not accept rule by experts. Second, 'in the absence of an articulate voice on the part of the masses,' experts will become 'a specialized class' that is 'shut off from knowledge of the needs which they are supposed to serve.' [...] Finally, Dewey argues that if experts isolate themselves from society, they become 'a class with private interests and private knowledge.' Government by experts is nothing but 'an oligarchy managed in the interests of the few'." (Brown 2009: 149f.). ${ }^{9}$ Scientism provides the worldview-background for technocratic/expertocratic conceptions like the one propagated by Eagleman. It is therefore crucial to expose its anti-democratic implications as clearly as possible.

\section{The Alternative to Scientism: Pragmatist and Democratic Pluralism}

16 In this section, I want to argue that the philosophers of classical pragmatism, especially John Dewey, have developed the conceptual means to avoid scientism, to embrace the actual varieties of human experience and also to make room for world-view pluralism, albeit with the crucial and very demanding constraint that the respective world-views and religions must be willing to participate in the democratic process. When the question concerning the relation between science and democracy is raised, showing how scientific expertise and democratic decision-making can be brought into a mutually enhancing arrangement is only one part of the problem. It is also necessary to counter what Habermas called the colonization of the life-world, that is the selfalienation of democratic communities, in this case caused by the intrusion of scientistic self-descriptions and exaggerated expectations addressed to technology. The diverse trans- and posthumanistic movements offer a glimpse of what may happen in the long run when scientism succeeds. Often, they are entangled with influential proponents of the digital industry and of AI-research like Ray Kurzweil or Anthony Levandowski. These movements differ widely from each other, but they all incline towards an empowerment of technological elites as opposed to Dewey's vision of the inclusion of as many forms and as many subjects of human experience as possible.

17 The argument I want to develop now depends upon Dewey's conception as articulated in his books Experience and Nature (1925/2008) and Logic. The Theory of Inquiry (1938/2008). Already in Experience and Nature, Dewey leaves no doubt that he a.) sees a decisive difference between ordinary and scientific experience, b.) holds that this difference pertains to different functions within the human life process and has no ontological implications and c.) rejects the "assumption of the identity of objects of knowledge and ultimately real objects" (Dewey 1925/2008: 26), that is the ontological basis for scientism. Scientific experience focuses upon relations between events conceived of as independent from what human beings care about, ${ }^{10}$ whereas in ordinary experience reality appears within the engaged mode of interaction with the social and physical environment. Both forms of experience are fallible and in need of reflective improvement, but both may reveal actual features of the natural world. In his late opus magnum, the Logic, Dewey expands this general stance to the idea that "scientific subject-matter is intermediate, not final and complete in itself" (Dewey 1938/2008: 72). Its partial autonomy stems from the fact that we have to bracket our human values and desires if we are to understand the workings of nature and thus to 
gain causally effective knowledge. But this bracketing is something transitory, a necessary but not sufficient stage in human experience and action. Therefore, scientific knowledge is able to rectify ordinary experience with regard to systematic relations existing between events and objects (the paradigmatic example being the explanation of the experience of the rising sun through the earth's rotation), but it has to be reintegrated into ordinary experience to give us the full picture. Aesthetic, moral, religious, ${ }^{11}$ etc., ways of experiencing also disclose facets of reality, facets inaccessible from the detached standpoint of methodological experience.

There exists an inner affinity between this Deweyan emphasis on the irreducible multitude of human experience and his ideal of democracy as inclusive and uninhibited communication. The ideal of a democratic form of life calls for a wide and nonscientistic understanding of experience. In a science-driven globalized world-economy, democracies are in desperate need of scientific expertise, yet a hegemony of scientistic worldviews (as distinct from the flourishing of science and its societal impact) would dry out the sources of pluralist democratic discourse. The main constraint for the proponents of religious worldviews is that with regard to those features of reality accessible by the sciences their authority has to be respected. Evolution-deniers, racists and proponents of verbally inspired holy scriptures, to give a few examples, have discredited themselves by disrespecting science. In broad strokes, this is what is implied in Dewey's general picture. I would like to add that scientism is not only detrimental for democracy but also a form of disrespecting science, even if it is propagated by scientists and science journalists. When, for example, Edward Wilson in his book Consilience. The Unity of Knowledge claims that "People need a sacred narrative" and suggests to take it from "the true evolutionary epic, retold as poetry" (Wilson 1999: 289), science has degenerated into pseudo-religion. ${ }^{12}$

19 As I have already pointed out, there is absolutely no realistic prospect that in the near future secular world-views and religions will lose their importance and yield to an experimental, piecemeal attitude abstaining from generalizing to comprehensive images of reality. That being the case, we'd better come up with a viable concept of how to integrate this manner of transcending the empirically given into our ideas of the democratic form of life. Getting the appropriate status of science within democratic societies right is an important part of this concept. The first part of the problem, namely the quest for better integrating social values with the course of inquiry and technological development, has gigantic dimensions and its solution is considerably aggravated by the dominance of economic interests. But the theoretical groundwork has, despite some shortcomings I see, already been delivered by Kitcher's pioneering work and especially his ideas about "the evolution of public knowledge" and "public reason" (chap. 4 and 6 of Kitcher 2011). The second part challenges us in ways not foreseeable from the viewpoint of the first. Pragmatist meliorism has to a.) integrate the lasting influence of religions and comprehensive world-views into its vision of the democratic way of life, and b.) develop criteria for assessing the proper role of science in this regard.

As to the first point, the pragmatist idea of an unreducible pluralism of experiences and their articulations, even on the highest level of comprehensive worldviews, raises the awareness for their contingency and counters the anti-democratic, regressive hope for integrating whole societies via a single overarching set of final values. But at the same time, it encourages democratic societies to foster all forms of dialogue and open 
conversation about values in the hope that what John Rawls called an "overlapping consensus" might be achieved - a consensus about a just society "affirmed by the opposing religious, philosophical and moral doctrines likely to thrive over generations" (Rawls 1987: 1). Rawls was definitely no pragmatist, but his acknowledgment of deeprooted worldview-pluralism as an inevitable social fact connects him with the classical pragmatist's insight into the "varieties of experience," to paraphrase William James.

Roberto Frega (2012), drawing on Rawls's concept of the burdens of judgment, has tackled the problem of irreducible pluralism in modern societies in a helpful manner. As he argues, disagreements in terms of moral and worldview-questions have to be accepted as being not only reasonable (that is, due to empirical constraints we cannot overcome) but also rational (Frega 2012: 137). This being so, the question is how to integrate them into what Frega calls a "wide view of democracy." His book from 2019 bearing that title contains a wealth of suggestions how democratic procedures, institutions and publics should be developed in accordance with the pragmatic spirit of pluralism and fallibility. Frega's "democratic experimentalism" highlights the tension between ordinary experience and expert knowledge, but it remains largely silent about the role of worldviews and religions within this context. It should, however, be possible to expand his approach in the direction of taking both science and religions seriously. The crucial point is this: If rational, not only reasonable disagreements are accepted as inevitably pertaining to comprehensive worldviews, and the reflective among their adherents are willing to accept that, religious traditions of sensemaking are insofar - at least partly released from being encapsulated in closed communities. They become available as contributions to an ongoing democratic exchange about values and meanings. Naturally, religious believers will not regard their experiences and convictions as being exhausted by their contribution to a pluralistic, experimental conversation about the common good. But they will be able to participate in this conversation without being forced to entirely bracket their most deep-seated attitudes. Similarly, the contributions of scientists to the value-laden questions of social life will more likely be accepted as important if articulated without the Pinkerian ideological pretense of expressing the only possible rational worldview.

This leads us to the second point: two opposite, but closely related misconceptions of science's relations to world-views and religions have to be avoided to enable "democratic experimentalism." Unsurprisingly, the first is the fundamentalist idea that from the standpoint of a given worldview or religion science should be limited to what is compatible with the mindset of the respective attitude. The proponents of scientism would definitely agree. But scientism, the idea that science is not only a necessary but also the only and sufficient source of world-view orientation, is almost as detrimental to the flourishing of democracies as religious fundamentalism. If we discard both attitudes, as appropriate, we have to embrace a limited version of world-view pluralism as a permanent condition of the democratic form of life, broadly in the same manner as the late John Rawls saw well-ordered societies as shaped by the overlapping consensus mentioned above. The scientific understanding of human beings, life in general and the universe contributes immensely to any non-fundamentalist world-view or religion, but it doesn't single out a specific one, because these generalized stances are to a large degree always shaped by non-methodic, personally engaged forms of experience. And it cannot be different since the raison d'être of worldviews is orientation for actors and their quest of having to lead a life. Dewey's theory of comprehensive experience and the non-final, albeit crucial role of science within it enables us to see why this is the 
case, why democratic pluralism includes those generalized attitudes, and why we should reject scientism as vehemently as all forms of religious fundamentalism.

\section{BIBLIOGRAPHY}

BROWN Mark B., (2009), Science in Democracy. Expertise, Institutions, and Representation, Cambridge, Ma./London, The MIT Press.

DEWEY John, (1903/2008), "Democracy in Education," in The Middle Works vol. 3, ed. by Jo Ann Boydston, Carbondale, Southern Illinois University Press.

DEWEY John, (1916/1985), "Democracy and Education," in The Middle Works vol. 9, ed. by Jo Ann Boydston, Carbondale, Southern Illinois University Press.

DEWEY John, (1925/2008), “Experience and Nature,” in The Later Works vol. 1, ed. by Jo Ann Boydston, Carbondale, Southern Illinois University Press.

DEWEY John, (1927/2008), “The Public and its Problems," in The Later Works vol. 2, ed. by Jo Ann Boydston, Carbondale, Southern Illinois University Press.

DEWEY John, (1930/2008), “Qualitative Thought," in The Later Works vol. 5, ed. by Jo Ann Boydston, Carbondale, Southern Illinois University Press.

DEWEY John, (1932/2008), “Ethics," in The Later Works vol. 7, ed. by Jo Ann Boydston, Carbondale, Southern Illinois University Press.

DEWEY John, (1934/1989), “Art as Experience,” in The Later Works vol. 10, ed. by Jo Ann Boydston, Carbondale, Southern Illinois University Press.

DEWEY John, (1934/2006), “A Common Faith,” in The Later Works vol. 9, ed. by Jo Ann Boydston, Carbondale, Southern Illinois University Press.

DEWEY John, (1938/2008), “Logic. The Theory of Inquiry,” in The Later Works vol. 12, ed. by Jo Ann Boydston, Carbondale, Southern Illinois University Press.

DEWEY John, (1939/2008), “Creative Democracy - The Task Before Us,” in The Later Works vol. 14, ed. by Jo Ann Boydston, Carbondale, Southern Illinois University Press.

DEWEY John, (2012), Unmodern Philosophy and Modern Philosophy, Carbondale, Southern Illinois University Press.

EAGLEMAN David, (2012), Incognito. The Secret Lives of the Brain, Edinburgh/London, Canongate.

FREGA Roberto, (2012), Practice, Judgment, and the Challenge of Moral and Political Disagreement. A Pragmatist Account, Lexington, Lanham.

FREGA Roberto, (2019), Pragmatism and the Wide View of Democracy, Basingstoke, Palgrave Macmillan.

JAMES William, (1902/1990), The Varieties of Religious Experience, New York, The Library of America. JAMES William, (1907/1981), Pragmatism, Indianapolis, In., Hackett Publishing. 
JUNG Matthias, (2016), "Qualitative Experience and Naturalized Religion - an Inner Tension in Dewey's Thought?," in Hermann Deuser, Hans Joas, Matthias Jung \& Magnus Schlette (eds.), The Variety of Transcendence. Pragmatism and the Theory of Religion, New York, Fordham University Press.

JUNG Matthias, (2019), Science, Humanism, and Religion. The Quest for Orientation, Basingstoke, Palgrave Macmillan.

KITCHER Philip, (2011), Science in a Democratic Society, New York, Prometheus Books.

KITCHER Philip, (2014), Life after Faith. The Case for Secular Humanism, New Haven and London, Yale University Press.

LANIER Jaron, (2006), Beware the Online Collective," Time, December 16. Online: [http:// content.time.com/time/magazine/article/0,9171,1570745,00.html].

METZINGER Thomas, (1998), “Anthropologie und Kognitionswissenschaft," in Peter Gold \& Andreas K. Engel (eds.), Der Mensch in der Perspektive der Kognitionswissenschaften, Frankfurt-a.-Main, Suhrkamp.

MIDGLEY Mary, (2010), Evolution as a Religion. Strange Hopes and Stranger Fears, London and New York, Taylor \& Francis, Routledge.

PAPPAS Gregory Fernando, (2015), “John Dewey and the Importance of the 'Qualitative' for Democracy," in Pablo Quintanilla \& Claudio Viale (eds.), El pensamiento pragmatista en la actualidad: conocimiento, lenguaje, religion, estética y política, Lima, Fondo Editorial PUCP.

PINKER Steven, (2013), "Science is Not Your Enemy. An Impassioned Plea to Neglected Novelists, Embattled Professors, and Tenureless Historians," The New Republic, August 7. Online: [https:// newrepublic.com/article/114127/science-not-enemy-humanities].

PINKER Steven, (2018), Enlightenment Now. The Case for Reason, Science, Humanism, and Progress, New York, Viking.

PUTNAM Hilary \& Ruth Anna PUTNAM, (2007), Pragmatism as a Way of Life. The Lasting Legacy of William James and John Dewey, Cambridge, Ma., Harvard University Press.

RAWLS John, (1987), “The Idea of an Overlapping Consensus,” Oxford Journal of Legal Studies, 7 (1), $1-25$.

RORTY Richard, (1989), Contingency, Irony, and Solidarity, Cambridge, Ma./London, Harvard University Press.

SANDEL Michael, (2010), Justice. What's the Right Thing to do?, London, Penguin Books.

WESTBROOK Robert B., (1991), John Dewey and American Democracy, Ithaca/London, Cornell University Press.

WILSON Edward O., (1999), Consilience. The Unity of Knowledge, New York, Vintage Books.

\section{NOTES}

1. "I am inclined to believe that the heart and final guarantee of democracy is in free gatherings of neighbors on the street corner to discuss back and forth what is read in uncensored news of the day [...]." (Dewey 1939/2008: 227).

2. For a comprehensive treatment of this complex issue, see my Science, Humanism, and Religion. The Quest for Orientation (Jung 2019). 
3. Note that this statement includes scientists, too. Whenever not acting in their professional role, they live their lives in qualitatively determined situations (actually, pragmatist philosophy of science suggests that even scientific inquiry cannot do without a qualitative sensibility to the importance vs. irrelevance of theories and experimental results).

4. In his paper "John Dewey and the Importance of the 'Qualitative' for Democracy" (Pappas 2015) Gregory F. Pappas argues very convincingly that taking the qualitative seriously must include careful attention to its contemporary distortions brought about e.g. by mass media: "The dangerous aspects of rhetoric and emotional persuasion are more significant today than during Dewey's time. The people are swayed by irrelevancy, amusement, and fear. They are seduced by images, propaganda, and demagoguery instead of by the force of argument." However, according to Pappas the solution to this lamentable predicament cannot be to bracket the qualitative dimension of human experience, but rather to restore it to its proper function. Democratic deliberation requires rigorous argument and critique, but it becomes cut off from the interests and values social conflicts are about if not guided by qualitative sensitivity.

5. According to Kitcher, religions are "refined" when religious truths are not put in the same category as questions of factual truth or falsehood (cf. Kitcher 2014: 88). Roughly, the contrast pertains between fundamentalist and refined religions.

6. See his A Common Faith (Dewey 1934/2006) and my critical assessment of his own confusion between methodological naturalism and worldview-naturalism: Jung (2016).

7. The problem is obviously related to the much debated question about Aristotelian and Kantian conceptions of the relation between the right and the good. Pragmatists find themselves more on the Aristotelian side and probably most of them would agree with Michael Sandel: "Many of the most hotly contested issues of justice and rights can't be debated without taking up controversial moral and religious questions. In deciding how to define the rights and duties of citizens, it's not always possible to set aside competing conceptions of the good life. And even when it's possible, it may not be desirable." (Sandel 2010: 243).

8. It should be obvious that to reject expertocracy is very different from rejecting the importance of experts. Without competent experts, no democracy could survive, as the current corona-crisis shows very clearly. But the most self-reflective among those experts, like in the case of the German virologist Christian Drosten, again and again alert the public to the fact that virological expertise is not the same thing as political decision-making and taking action.

9. The quotes within the quote are taken from Dewey's The Public and its Problems (Dewey 1927/2008).

10. This claim may sound strange when made by a pragmatist, since pragmatists conceive of science not as the freestanding and disinterested search for knowledge but as a human enterprise driven by our desire to understand and control nature in the interest of human values. Yet in order to achieve this, Dewey emphasizes, we have to methodically abstract from the first-personal perspective. As Francis Bacon has pointed out already in early modernity, "natura non nisi parendo vincitur" (Nature, to be commanded, must be obeyed).

11. Dewey has contributed substantial work to each of these adverbial dimensions of experience: Cf. his Ethics (Dewey 1932/2008), Art as Experience (Dewey 1934/1989), and his Terry Lectures A Common Faith (Dewey 1934/2006).

12. For a critical account of evolution-based scientistic approaches see Mary Midgley's Evolution as a Religion (Midgley 2010). 


\section{ABSTRACTS}

Science is among the most crucial factors for the functioning of modern democracies, yet we tend to conceive of the science-system as mainly driven by its own internal logic and connected with the rest of society via input-output-relations. But does that mean that science is independent from the political system and the cultural life-form into which it is embedded, or is science intrinsically related to democracy? While authors like Hilary Putnam and Philip Kitcher have already tackled these questions, an important part of the problem has hitherto been largely neglected: how is science related to the worldviews one may justifiably hold in a pluralistic society? Arguing with Dewey's emphasis on the irreducible multitude of human experience, the paper defends a conception of wide "democratic experimentalism" (Frega), in which compatibility with science is crucial for the rational acceptability of worldviews and religions, but scientism is vigorously rejected.

\section{AUTHOR}

\section{MATTHIAS JUNG}

Universität Koblenz-Landau

mjung[at]uni-koblenz.de 